\title{
Equilibrium, Kinetic and Thermodynamic Studies of Analgesic Removal by Thin Coated Activated Carbon
}

\author{
Muhamad Sharafee Shamsudin and Suzylawati Ismail* \\ School of Chemical Engineering, Engineering Campus, \\ Universiti Sains Malaysia, 14300 Nibong Tebal, \\ Pulau Pinang, Malaysia.
}

"Corresponding author: chsuzy@usm.my

Published online: 30 June 2020

To cite this article: Muhamad Sharafee Shamsudin and Suzylawati Ismail (2020). Equilibrium, kinetic and thermodynamic studies of analgesic removal by thin coated activated carbon. Journal of Engineering Science, 16(1), 47-63, https://doi.org/10.21315/ jes2020.16.1.4.

To link to this article: https://doi.org/10.21315/jes2020.16.1.4

\begin{abstract}
Acetaminophen (analgesic) also known as paracetamol, usually used to reduce moderate pain such as headaches, menstrual periods, cold/flu aches and fever. This is one of the pharmaceutical products generally consume and dispose to the environment and become pharmaceutical pollution. This research, study a new approach applying adsorption concept. Thin coated activated carbon (TCAC) for adsorption of acetaminophen was investigated. The TCAC is formulated using Epoxidised Neutral Rubber (ENR-50) and poly(vinyl) chloride (PVC) as binders with activated carbon as an adsorbent, then was coated on white cotton fabric via brushing technique. Characterisation analysis using Scanning Electron Microscope-Energy Dispersive X-ray (SEM-EDX) and BrunauerEmmett-Teller (BET) analysis were performed. The pore volume and surface area of the $T C A C$ are $0.07 \mathrm{~cm}^{3} \mathrm{~g}^{-1}$ and $64.3 \mathrm{~m}^{2} \mathrm{~g}^{-1}$, respectively. The TCAC was evaluated through varies parameters including different initial concentrations and temperatures. The amount of acetaminophen as adsorbate, $50 \mathrm{mg} \mathrm{L}^{-1}$, able to be adsorbed up to $32.43 \mathrm{mg} \mathrm{g}^{-1}$ into TCAC within $5 \mathrm{~h}$. The result of equilibrium and kinetic studies indicated that Langmuir isotherm model and pseudo-second-order, respectively, are best fitted the adsorption of acetaminophen onto TCAC. It was decisive that the adsorption process of acetaminophen on TCAC is spontenoous $\left(\Delta G^{\circ}<0\right)$ and exothermic $\left(\Delta H^{\circ}<0\right)$ through thermodynamic studies.
\end{abstract}

Keywords: analgesic, acetaminophen, TCAC, thin coated activated carbon, activated carbon, adsorption 


\section{INTRODUCTION}

Pharmaceutical emerging pollutant considered as rare pollutants has been detected nowadays. This kind of pollutant has attracted much attention among researchers because of growing pharmaceutical manufacturing industries and human behaviour. There are few categories listed under pharmaceutical emerging pollutants have been detected which are antibiotic, analgesic, antiepileptic, dopamine, opioids, antiseptics, steroid hormones and stimulant. ${ }^{1}$ However, the most common categories has been found in water stream is analgesic. Under analgesic categories there are several compound been highlighted which are acetaminophen, codeine, ibuprofen and naproxen. ${ }^{2}$ In the United States, it was reported detection frequency exceeding $30 \%$ of the water stream from 47 groundwater sites selected. ${ }^{3}$ Then, wastewater sample has been collected from five different types of sewage treatment plants in Johor, Malaysia. ${ }^{1}$ There are nine pharmaceutical compounds (acetaminophen, lincomycin, trimethoprim, sulfamethazine, sulfamethoxazole, clarithromycin, carbamazepine, ibuprofen, and naproxen) that are the most frequently consumed by resident living nearby of these sewage treatment plant. Acetaminophen was recorded the highest concentration has been detected able to reach $40.17 \mathrm{mg} \mathrm{L}^{-1}$. Consequent of that all of the pharmaceutical compounds are potentially harmful to the aquatic organisms and human life in the future. These substances enter the environment largely from wastewater treatment, aquaculture treatment and leaking landfills., ${ }^{4,5}$ Other exposure pathways exist, including emission from manufacturing industries, disposal of unused medicine to landfill and flushed down the toilet, irrigation with wastewater from hospitals, veterinary medicine from the hard surface in farmyards and disposal of carcasses of treated animals..$^{6-8}$ Other than that, this pollutant is able to enter the environment when a person who takes medicine, up to $9 \%$ of medicine excreted out of the body through urination, then it flushed down the toilet and mixed with wastewater. ${ }^{9}$

In Malaysia, pharmaceutical waste from hospital, clinic and any medical store has been regulated under government on disposal of expired, unused and defected medicine through Environmental Quality (Scheduled Waste) Regulation 2005. However, this regulation does not apply to residencies, aquaculture activities and others, where there has an irresponsible citizen that disposed the medicine improper ways to landfills and also mixed together with their daily food waste, then disposed in flushing bowls. Through that pathway, it showed how easy this pollutant may enter the environment. The pollutant concentration stated by a group of researchers in Johor, Malaysia, frequently detected. ${ }^{2}$ Moreover, these compounds with long-term exposure may lead to mutagenic and genotoxic effects on aquatic 
life. As a consequence, the compounds drastically decrease the reproductive success in aquatic life. The most critical effect arises from the exposure to these compounds is their ability to cause the liver and reproductive damage in human health, accumulation tissues and inhibition of cell proliferation. ${ }^{10}$

By disposing the medicine in toilet bowls, it will eventually ended up in sewage treatment plant. Unfortunately, the treatment plant did not have any specific treatment for pharmaceutical waste. So, the water will not be treated accordingly before discharged and distributed back to the residents. According to previous research, there are several conventional sewage treatment processes to facilitate in removal of these compounds, such as coagulation, sedimentation, filtration but it inefficient because only able to remove about $10 \%$ to $20 \%$ of these compounds. ${ }^{11}$ Nowadays, domestic sewage treatment is using biological treatment systems. In Malaysia, commonly included extended aeration, oxidation ditch, oxidation pond, sequencing batch bioreactor. The biological treatment system is a reliable treatment system especially in removing high organic and nutrient content from sewage. ${ }^{12}$ However, it is still not completely eliminate the pollutants before distributed to residents. ${ }^{2}$

Presently, this research is aimed to develop a novel adsorption technology that will reduce the amount of pharmaceutical pollutant exist in the environment. The existing adsorption process requires several types of equipment to operate such column, pump, valve and need energy consumption to run the system. In this research study, the technology is relatively simple to be applied in the wastewater treatment system. It can be added onto the existing process without affecting their current operation. Therefore, the performance of TCAC being investigated in the application of acetaminophen removal from the aqueous solution.

\section{MATERIALS AND METHODS}

\section{$2.1 \quad$ Chemicals}

Acetaminophen was purchased from BT Science Sdn. Bhd. The chemical structure and physical properties of acetaminophen are shown in Table $1 .{ }^{13}$ Epoxidised Neutral Rubber with $50 \%$ mol of epoxidation (ENR-50) was provided by School of Chemistry, Universiti Sains Malaysia. Toluene and dichloromethane were supplied by BT Science Sdn. Bhd. PVC, commercial untreated activated carbon and kaolinite were obtained from Sigma-Aldrich Sdn. Bhd. 
Table 1: Properties and chemical structure of acetaminophen.

\begin{tabular}{ll}
\hline Chemical structure & Analgesics \\
Category & $\mathrm{N}-(4$-hydroxyphenyl) acetamide \\
IUPAC name & $151.165 \mathrm{~g} \mathrm{~mol}^{-1}$ \\
Molecular weight & Odourless \\
Odour & White powder \\
Colour & Slightly bitter \\
Taste & $168^{\circ} \mathrm{C}$ \\
Melting point & $>22.7 \mu \mathrm{g} \mathrm{mL}^{-1}$ \\
Solubility &
\end{tabular}

\subsection{Preparation of Adsorbate}

The stock solution of adsorbate (Acetaminophen) was prepared before the experiment started by weighing $0.4 \mathrm{~g}$ of acetaminophen using analytical balance (A\&D Company, Limited, model HR-250A) and completely dissolved into $2 \mathrm{~L}$ of distilled water. The stock solution was then diluted to several studied concentrations. The dilution is calculated using Equation 1. The detection of adsorbate via UVvis spectroscopy, the calibration curve of acetaminophen have been created with wavelength $287 \mathrm{~nm}$ respectively through various concentration $(1,10,20,30,40$, 50 and $100 \mathrm{mg} \mathrm{L}^{-1}$ ).

$$
\mathrm{M}_{1} \mathrm{~V}_{1}=\mathrm{M}_{2} \mathrm{~V}_{2}
$$

Where:

$$
\begin{array}{ll}
\mathrm{M}_{1}= & \text { Concentration of stock solution }\left(200 \mathrm{mg} \mathrm{L}^{-1}\right) \\
\mathrm{V}_{1}= & \text { Volume of stock solution need to be diluted (L) } \\
\mathrm{M}_{2}= & \text { Concentration required (mg L-1) } \\
\mathrm{V}_{2}= & \text { Volume need to be tested (L) }
\end{array}
$$

\subsection{Preparation of Thin Coated Activate Carbon (TCAC)}

ENR-50 solid was dissolved using the reflux process, where $24.80 \mathrm{~g}$ of solid ENR-50 was mixed with $250 \mathrm{~mL}$ of toluene. Then, the mixture was left for reflux under the temperature of $85^{\circ} \mathrm{C}$ to $90^{\circ} \mathrm{C}$ for $80 \mathrm{~h} .{ }^{14}$ After that, $0.80 \mathrm{~g}$ of PVC 
in $35 \mathrm{~mL}$ of dichloromethane was dissolved via sonication for $30 \mathrm{~min}$. Then, $4 \mathrm{~g}$ of ENR-50 solution was mixed with $65 \mathrm{~mL}$ toluene and the mixture was shaken for 1 min. Next, $4 \mathrm{~g}$ of activated carbon was added and the mixture was sonicated for $6 \mathrm{~h} .{ }^{15}$ After being sonicated, the mixture was divided into $6 \mathrm{~mL}$ for each coating. The solution was applied onto a cotton fabric (dimension $210 \mathrm{~mm} \times 50 \mathrm{~mm}$ ) via brushing technique, and dried in the oven at $100^{\circ} \mathrm{C}$ for $5 \mathrm{~min}$.

\subsection{Batch Adsorption Studies}

The acetaminophen solution was prepared from a stock solution (200 $\mathrm{mg} \mathrm{L}^{-1}$ ). The adsorption performance was evaluated through various initial concentrations $\left(5\right.$ to $\left.100 \mathrm{mg} \mathrm{L}^{-1}\right)$ and temperature $\left(30^{\circ} \mathrm{C}, 40^{\circ} \mathrm{C}\right.$ and $\left.50^{\circ} \mathrm{C}\right)$. The TCAC strip was weighed prior to the testing. Then, the strip was placed to the interior wall of $250 \mathrm{~mL}$ beaker and adsorption process start. The sample solution was collected for every $30 \mathrm{~min}$ interval and analysed it. The experiment was continued for $5 \mathrm{~h}$. The adsorption isotherm study was performed applying the recorded experimental results.

The equilibrium adsorption values were calculated using the equations below. The amount of acetaminophen adsorbed, $\mathrm{q}_{\mathrm{t}}\left(\mathrm{mg} \mathrm{g}^{-1}\right)$ on the coated strip at a particular temperature was determined using Equation 2:

$$
\mathrm{q}_{\mathrm{t}}=\frac{\left(\mathrm{C}_{0}-\mathrm{C}_{\mathrm{t}}\right)}{\mathrm{W}}
$$

where $\mathrm{C}_{0}$ and $\mathrm{C}_{\mathrm{t}}\left(\mathrm{mg} \mathrm{L}^{-1}\right)$ are initial concentration of acetaminophen and concentration at the time $t$, respectively. $\mathrm{V}$ is the volume (in L) is the volume of acetaminophen solution that has been tested and $\mathrm{W}$ is the mass (in gram) of adsorbent used for each coating.

The equilibrium adsorption capacity $\left(\mathrm{q}_{\mathrm{e}}\right)$ was determined according to the following equation, Equation 3:

$$
\mathrm{q}_{\mathrm{e}}=\frac{\left(\mathrm{C}_{0}-\mathrm{C}_{\mathrm{e}}\right) \mathrm{V}}{\mathrm{W}}
$$

\subsection{Adsorption Isotherm Studies}

The nature of adsorbent coating toward the adsorption of acetaminophen was examined through Langmuir, Freundlich and Temkin isotherm models. 


\subsubsection{Langmuir adsorption isotherm}

The Langmuir isotherm is the most common and very popular model used by researchers in order to quantify the amount of adsorbate on an adsorbent as a function of particular concentration at a given temperature. Basic theoretical assumes monolayer coverage of adsorbate and takes place homogenous site of adsorbent surface. Therefore, at equilibrium, a saturation point is reached where no further interaction can occur, once the adsorbate molecule occupied a site. ${ }^{16}$ The equation as calculated using Equation $4:{ }^{17}$

$$
\mathrm{q}_{\mathrm{e}}=\frac{\mathrm{q}_{\max } \mathrm{K}_{\mathrm{L}} \mathrm{C}_{\mathrm{e}}}{1+\mathrm{K}_{\mathrm{L}} \mathrm{C}_{\mathrm{e}}}
$$

The separation factor $\left(R_{L}\right)$ is used to evaluate if the adsorption if unfavourable $\left(\mathrm{R}_{\mathrm{L}}>1\right)$, favourable $\left(0<\mathrm{R}_{\mathrm{L}}<1\right)$, linear $\left(\mathrm{R}_{\mathrm{L}}=1\right)$ or irreversible $\left(\mathrm{R}_{\mathrm{L}}=0\right), \mathrm{R}_{\mathrm{L}}$ can be calculated as: ${ }^{18}$

$$
\mathrm{R}_{\mathrm{L}}=\frac{1}{1+\mathrm{K}_{\mathrm{L}} \mathrm{C}_{\mathrm{O}}}
$$

\subsubsection{Freundlich adsorption isotherm}

The Freundlich isotherm was practised for adsorption on heterogenous surface energy system where the binding site is not equivalent. This model is describing the adsorption is multilayer adsorption of adsorbate and heterogeneous of adsorbent surface. ${ }^{19}$ Adsorption intensity or surface heterogeneity becoming more heterogeneous as its value gets closer to zero. The equation of Freundlich isotherm as calculated using equation below: ${ }^{20}$

$$
\mathrm{q}_{\mathrm{e}}=\mathrm{k}_{\mathrm{F}}\left(\mathrm{C}_{\mathrm{e}}\right)^{1 / \mathrm{n}}
$$

\subsubsection{Temkin adsorption isotherm}

Temkin isotherm model studied the heat of adsorption and the adsorbate-adsorbent interaction on adsorption. By ignoring the extremely low and large value of concentration, the model assumes that heat od adsorption of all molecules in the layer would decrease linearly that logarithmic with coverage..$^{21}$ The equation Temkin is calculated using Equation $7^{22}$ where related parameters are defined in Table 2 . $\mathrm{R}$ represents the universal gas constant $\left(8.314 \mathrm{~J}\right.$ mol. $\left.\mathrm{K}^{-1}\right)$ and $\mathrm{T}$ is absolute temperature in Kelvin.

$$
\mathrm{q}_{\mathrm{e}}=\left(\frac{\mathrm{RT}}{\mathrm{b}}\right) \ln \left(\mathrm{k}_{\mathrm{T}} \mathrm{C}_{\mathrm{e}}\right)
$$


Table 2: Parameters and definition of isotherm models.

\begin{tabular}{|c|c|}
\hline Parameter & Definition \\
\hline $\mathrm{C}_{\mathrm{O}}$ & Initial concentration $\left(\mathrm{mg} \mathrm{L}^{-1}\right)$ \\
\hline \multirow[t]{2}{*}{$\mathrm{C}_{\mathrm{e}}$} & Concentration at equilibrium state $\left(\mathrm{mg} \mathrm{L}^{-1}\right)$ \\
\hline & Langmuir Model \\
\hline $\mathrm{q}_{\mathrm{m}}$ & Maximum adsorption capacity $\left(\mathrm{mg} \mathrm{g}^{-1}\right)$ \\
\hline \multirow[t]{2}{*}{$\mathrm{k}_{\mathrm{L}}$} & Langmuir isotherm constant $\left(\mathrm{L} \mathrm{mg}^{-1}\right)$ \\
\hline & Freundlich Model \\
\hline $\mathrm{k}_{\mathrm{F}}$ & Freundlich isotherm constant $\left(\mathrm{mg} \mathrm{g}^{-1} \cdot\left(\mathrm{L} \mathrm{mg}^{-1}\right)^{1 / n}\right)$ \\
\hline \multirow[t]{2}{*}{$\mathrm{n}$} & Adsorption intensity \\
\hline & Temkin Model \\
\hline $\mathrm{k}_{\mathrm{T}}$ & Temkin isotherm equilibrium binding constant $\left(\mathrm{L} \mathrm{mg}^{-1}\right)$ \\
\hline $\mathrm{b}$ & Constant related to the heat of adsorption $\left(\mathrm{J} \mathrm{mol}^{-1}\right)$ \\
\hline
\end{tabular}

\subsection{Error Analysis}

The optimisation procedure requires an error function to be defined in order to evaluate the best fit of the isotherm to experimental equilibrium data. The correlation coefficient for non-linear, $\mathrm{r}^{2}$ (close to 1 ) was solved using Solver Microsoft Excel, as calculated using Equation 8. Error function was calculated for all isotherm models and those with the lowest value of error analysis was selected as the best model to describe the experimental data. In this study, Average Relative Error (ARE) was used as Equation 9.

$$
\begin{aligned}
& \mathrm{r}^{2}=\frac{\sum\left(\mathrm{q}_{\mathrm{e}, \text { cal }}-\mathrm{q}_{\mathrm{e}, \text { ave }}\right)^{2}}{\sum\left(\mathrm{q}_{\mathrm{e}, \mathrm{eal}}-\mathrm{q}_{\mathrm{e}, \text { ave }}\right)^{2}+\sum\left(\mathrm{q}_{\mathrm{e}, \text { cal }}-\mathrm{q}_{\mathrm{e}, \text { exp }}\right)^{2}} \\
& \text { ARE }=\sum\left|\frac{\mathrm{q}_{\mathrm{e}, \text { exp }}-\mathrm{q}_{\mathrm{e}, \text { cal }}}{\mathrm{q}_{\mathrm{e}, \text { exp }}}\right|
\end{aligned}
$$

where $\mathrm{q}_{\mathrm{e}, \text { exp }}\left(\mathrm{mg} \mathrm{g}^{-1}\right)$ and $\mathrm{q}_{\mathrm{e} \text {, cal }}\left(\mathrm{mg} \mathrm{g}^{-1}\right.$ ) are the adsorption capacity from experimental data and calculated from the model, respectively. While $\mathrm{q}_{\mathrm{e}, \mathrm{ave}}$ $\left(\mathrm{mg} \mathrm{g}^{-1}\right)$ is represent as average adsorption capacity.

\subsection{Kinetic Studies}

In 1898, Lagergren's kinetics equation was the first one in describing the adsorption of a liquid-solid system based on solid capacity. The first order rate equation is also known as pseudo-first-order. ${ }^{23}$ The equation is presented as Equation 10: 


$$
\log \left(q_{e}-q_{t}\right)=\log q_{e}-\frac{k}{2.303} t
$$

where $\mathrm{q}_{\mathrm{e}}$, equilibrium adsorption capacity $\left(\mathrm{mg} \mathrm{g}^{-1}\right), \mathrm{q}_{\mathrm{t}}$ is the adsorption capacity $\left(\mathrm{mg} \mathrm{g}^{-1}\right)$ at time $\mathrm{t}(\mathrm{min})$ and $\mathrm{K}$ is the constant of pseudo-first-order rate $\left(1 \mathrm{~min}^{-1}\right)$. The constants of pseudo-first-order can be defined by plotting $\log \left(\mathrm{q}_{\mathrm{e}}-\mathrm{q}_{\mathrm{t}}\right)$ against $\mathrm{t}$.

In 1999, Ho and McKay proposed a pseudo-second-order equation that explained the amount of adsorbate captured on the adsorbent. ${ }^{24}$ The pseudosecond-order is a chemisorption equation and the non-linear equation was expressed by Equation 11:

$$
\frac{1}{\mathrm{q}_{\mathrm{t}}}=\frac{1}{\mathrm{~K}_{2} \mathrm{q}_{\mathrm{e}}^{2}}+\frac{\mathrm{t}}{\mathrm{q}_{\mathrm{e}}}
$$

where $\mathrm{q}_{\mathrm{t}}$ and $\mathrm{q}_{\mathrm{e}}$ is the amount of adsorption capacity $\left(\mathrm{mg} \mathrm{g}^{-1}\right)$ at time $\mathrm{t}(\mathrm{min})$ and at equilibrium, respectively. Then, $\mathrm{K}_{2}$ is the rate constant of the pseudo-second-order equation ( $\mathrm{g} \mathrm{mg} \cdot \mathrm{min}^{-1}$ ). The constant of pseudo-second-order kinetic can be defined by plotting $\mathrm{t}_{\mathrm{t}}^{-1}$ against $\mathrm{t}$.

\subsection{Thermodynamic Studies}

Thermodynamic parameter such as standard enthalpy $\Delta \mathrm{H}^{\circ}$, entropy change $\Delta \mathrm{S}^{\circ}$ and Gibbs free energy change $\Delta \mathrm{G}^{\circ}$ are studied to evaluate the feasibility of the adsorption process. The experiments are evaluated based on different temperature $(303,313$ and $323 \mathrm{~K})$. The thermodynamic value was calculated with the following equations: ${ }^{25}$

$$
\begin{aligned}
\Delta \mathrm{G}^{\circ} & =-\mathrm{RT} \ln \mathrm{k}_{\mathrm{L}} \\
\Delta \mathrm{G}^{\circ} & =\Delta \mathrm{H}^{\circ}-\mathrm{T} \Delta \mathrm{S}^{\circ} \\
\ln \mathrm{k}_{\mathrm{L}} & =-\frac{-\Delta \mathrm{H}^{\circ}}{\mathrm{R}} \frac{1}{\mathrm{~T}}+\frac{\Delta \mathrm{S}^{\circ}}{\mathrm{R}} \\
\mathrm{k}_{\mathrm{L}} & =\frac{\mathrm{q}_{\mathrm{e}}}{\mathrm{C}_{\mathrm{e}}}
\end{aligned}
$$

where, $\mathrm{R}$ is the universal gas constant $\left(8.314 \mathrm{~J}\right.$ mol. $\left.\mathrm{K}^{-1}\right), \mathrm{T}$ is the absolute temperature in Kelvin $(\mathrm{K})$ and $\mathrm{k}_{\mathrm{L}}$ is equilibrium constant. The linear graph is plotted $\ln \mathrm{k}_{\mathrm{L}}$ against $1 / \mathrm{T} . \Delta \mathrm{H}^{\circ}$ and $\Delta \mathrm{S}^{\circ}$ are determined from the slope and intercept of the graph respectively. Then, $\Delta \mathrm{G}^{\circ}$ is calculated using Equation 13 with varies temperatures $(303,313$ and $323 \mathrm{~K})$. 


\subsection{Apparatus and Instrumentation}

The apparatus used were $250 \mathrm{~mL}$ beaker, magnetic stirrer and cuvette (Quartz material). A magnetic stirrer (Multi Hotplate Stirrer WISD Laboratory Instrument SMHS-6) was used for mixing the slurry and adsorbate homogeneously. The UV-vis, spectrophotometer (Shimadzu UV-1800) was employed to measure the concentration of acetaminophen. The coating solution was dissolved by sonication process (model Elmasonic S80H). Drying oven (Constance Germany) was used to dry the TCAC. The surface morphology and content of the elements in TCAC was evaluated by using Scanning Electron MicroscopeEnergy Dispersive X-ray (SEM-EDX) spectroscopy (model Crest System (M) Sdn. Bhd. Quanta Feg 450). For BET analysis, a piece of TCAC (dimension $10 \mathrm{~mm} \times 30 \mathrm{~mm}$ ) was tested. The surface area, total pore volume and pore size of the TCAC and commercial AC were determined in nitrogen adsorption isotherm at $77 \mathrm{~K}$ using a BET surface analyser (Micromeritics model ASAP 2000, Nocross, GA).

\section{RESULTS AND DISCUSSION}

\subsection{Characterisation}

The scanning electron microscopy analysis captured the images of surface morphology of TCAC for before and after adsorption as illustrated in Figure 1. The activated carbon fully coated on white cotton fabric. The adsorbent with varies size was strongly attached through binder (ENR-50 and PVC). There is a huge amount of small particle of activated carbon, therefore, the surface area for adsorption can be increased. No obvious sign of acetaminophen attached to the TCAC, but it has been proven through EDX analysis. The main elements representing the compound of ENR-50, PVC and activated carbon which is carbon, oxygen, and chloride detected in high amounts as illustrated in Figure 2(a) and 2(b). Table 3 was summarised as the weight percentage of the elements. The nitrogen $(2.14 \%)$ has been detected which indicated the element of acetaminophen compound as shown in Figure 2(b). Therefore, it is proven there is an interaction between the acetaminophen and the surface of TCAC. The result of BET analysis demonstrated that the surface area of commercial AC decreased drastically when it introduced in TCAC $\left(948.1 \mathrm{~m}^{2} \mathrm{~g}^{-1}\right.$ to $\left.64.3 \mathrm{~m}^{2} \mathrm{~g}^{-1}\right)$. A similar pattern also observed in pore volume analysis, where the decreasing values from $0.94 \mathrm{~cm}^{3} \mathrm{~g}^{-1}$ to $0.07 \mathrm{~cm}^{3} \mathrm{~g}^{-1}$. However, there is some increment in pore size diameter from $39.6 \AA$ to $45.1 \AA$. According to the research by Bahrudin and Nawi (2017), similar trends of decreasing surface area and pore volume whilst the pore size diameter is increasing when ENR-50 and PVC were introduced as a coating. ${ }^{15}$ 


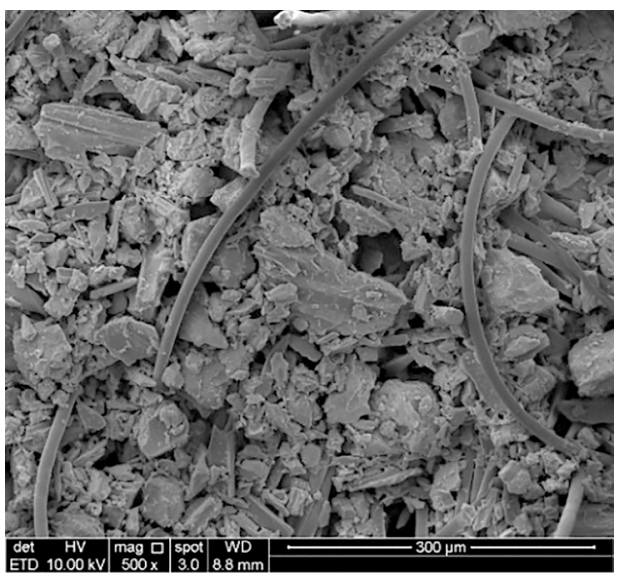

(a)

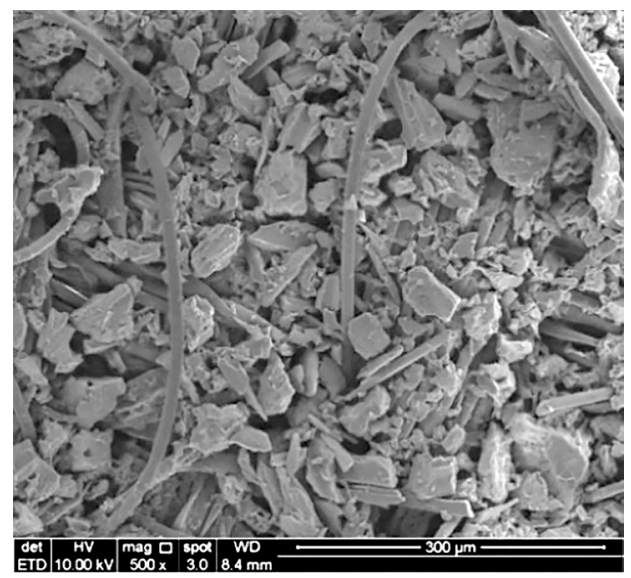

(b)

Figure 1: SEM images of TCAC (a) before (Mag. $\times 500)$ and (b) after adsorption process (Mag. $\times 500)$.

\subsection{Adsorption Isotherm Studies}

Table 4 summarised the adsorption isotherm models for Langmuir, Freundlich and Temkin for the TCAC at $30^{\circ} \mathrm{C}$ and Figure 3 showed the plotted graph of comparison non-linear isotherm models. The data show obvious distinction among all the three models. The data were obtained from the experiments, it showed that Langmuir model was the best fitted which determined through correlation coefficient $\left(\mathrm{r}^{2}\right)$, where the values for Langmuir model (0.999) were higher than Freundlich and Temkin models, 0.0.764 and 0.796 respectively. However, this result was supported by error analysis which are Langmuir (0.05), Freundlich (0.97) and Temkin (1.72). Therefore, the result proved Langmuir isotherm models is the best fitted isotherm or adsorption process of TCAC onto acetaminophen. Langmuir model indicates the adsorption is monolayer coverage of these adsorbates on the surface of TCAC and take place at specific homogenous site on the adsorbent, where no further adsorption can occur when a site is occupied with adsorbate. ${ }^{26}$ The other main characteristic of Langmuir isotherm can be expressed by dimensionless constant called equilibrium parameter, $R_{L}$ which indicates the type of isotherm. The $\mathrm{R}_{\mathrm{L}}$ value between 0 and 1 indicates favourable adsorption, $\left(R_{L}>1\right)$ is unfavourable, $\left(R_{L}=1\right)$ is linear and $\left(R_{L}=0\right)$ is irreversible. ${ }^{27}$ According to the results, the adsorption of acetaminophen onto TCAC has shown a favourable process by having RL value was 0.87 . 


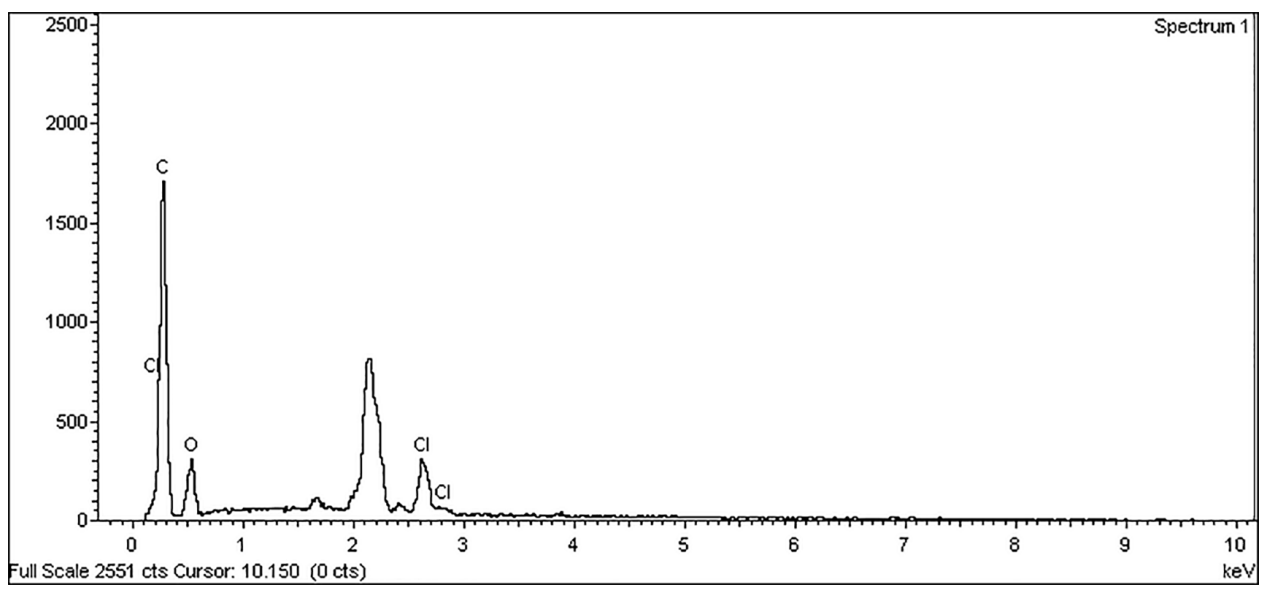

(a)

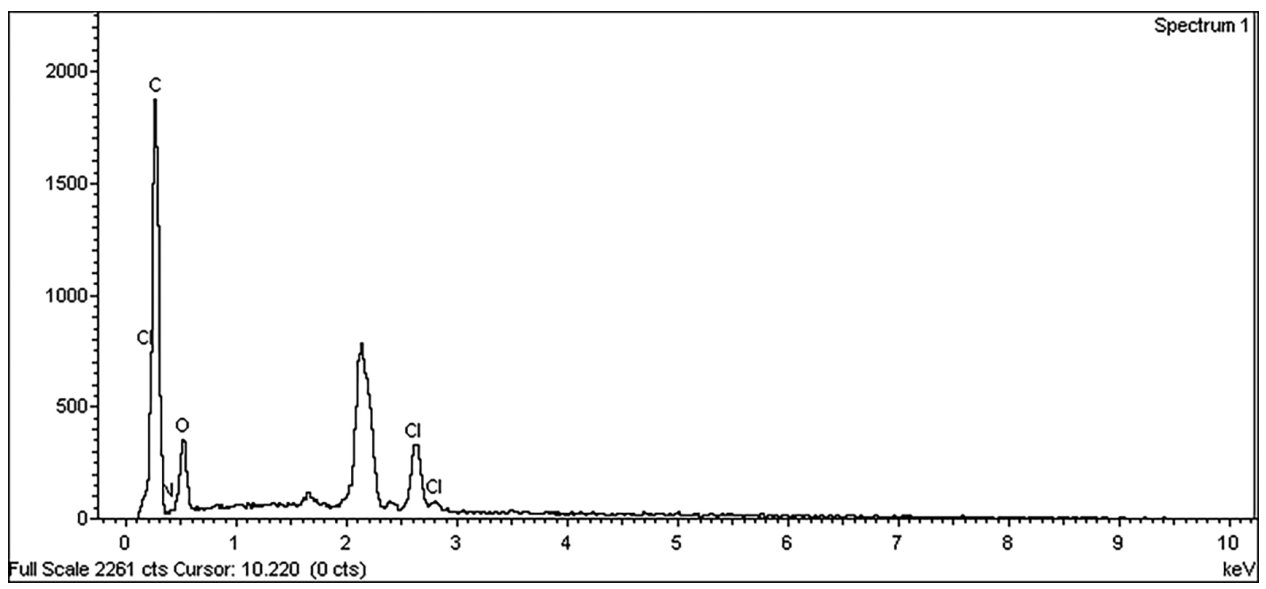

(b)

Figure 2: EDX analysis (a) before and (b) after adsorption.

Table 3: The weight percentage of elements detected from EDX analysis.

\begin{tabular}{lcccc}
\hline \multirow{2}{*}{ Items } & \multicolumn{4}{c}{ Elements weight percentage (wt. \%) } \\
\cline { 2 - 5 } & Carbon, C & Oxygen, O & Chloride, Cl & Nitrogen, N \\
\hline Before & 76.01 & 11.88 & 12.12 & - \\
After & 72.13 & 15.46 & 10.27 & 2.14 \\
\hline
\end{tabular}


Table 4: Summary of adsorption isotherms.

\begin{tabular}{|c|c|c|c|c|c|c|c|c|c|c|}
\hline \multicolumn{2}{|c|}{ Models } & \multicolumn{3}{|c|}{ Langmuir } & \multicolumn{3}{|c|}{ Freundlich } & \multicolumn{3}{|c|}{ Temkin } \\
\hline $\begin{array}{c}\mathrm{C}_{\mathrm{e}} \\
\left(\mathrm{mg} \mathrm{L}^{-1}\right)\end{array}$ & $\begin{array}{c}\mathrm{q}_{\mathrm{e}, \exp } \\
\left(\mathrm{mg} \mathrm{g}^{-1}\right)\end{array}$ & $\begin{array}{c}\mathrm{q}_{\mathrm{e}, \mathrm{cal}} \\
\left(\mathrm{mg} \mathrm{g}^{-1}\right)\end{array}$ & ARE & $\mathrm{r}^{2}$ & $\begin{array}{c}\mathrm{q}_{\mathrm{e}, \mathrm{cal}} \\
\left(\mathrm{mg} \mathrm{g}^{-1}\right)\end{array}$ & ARE & $\mathrm{r}^{2}$ & $\begin{array}{c}\mathrm{q}_{\mathrm{e}, \mathrm{cal}} \\
\left(\mathrm{mg} \mathrm{g}^{-1}\right)\end{array}$ & ARE & $\mathrm{r}^{2}$ \\
\hline 4.63 & 1.35 & 1.38 & & & 1.35 & & & 1.35 & & \\
\hline 19.63 & 8.76 & 8.92 & & & 8.76 & & & 20.61 & & \\
\hline 29.35 & 32.43 & 34.43 & 0.05 & 0.999 & 14.75 & 0.97 & 0.796 & 25.97 & 1.72 & 0.796 \\
\hline 50.16 & 37.87 & 37.71 & & & 29.55 & & & 33.12 & & \\
\hline 73.38 & 40.13 & 39.89 & & & 48.38 & & & 38.19 & & \\
\hline
\end{tabular}

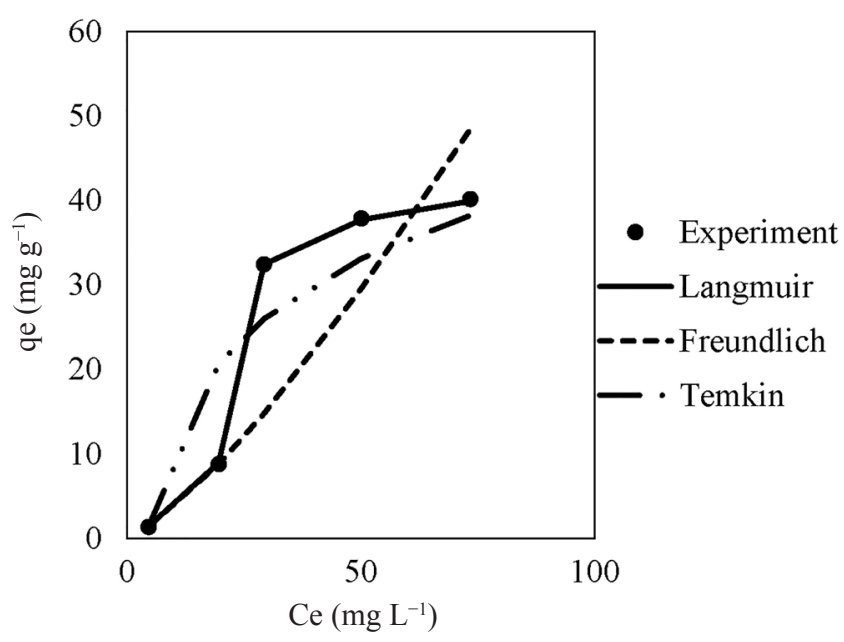

Figure 3: Comparison non-linear for Langmuir, Freundlich and Temkin isotherm models at $30^{\circ} \mathrm{C}$.

\subsection{Adsorption Kinetic Studies}

The adsorption kinetics of acetaminophen onto TCAC were evaluated through pseudo-first-order and pseudo-second-order models on the data that was obtained from the experimental studies. The results were tabulated in Table 5. From the data, it shows that pseudo-second-order has higher correlation coefficient, $\left(\mathrm{R}^{2}=0.935\right.$ to 0.998$)$ compared to pseudo-first-order $\left(\mathrm{R}^{2}=0.468\right.$ to 0.947). Moreover, the adsorption capacity calculated $\left(\mathrm{q}_{\mathrm{e}, \text { cal }}\right)$ value agree with the experimental data $\left(\mathrm{q}_{\mathrm{e} \text {, exp }}\right)$. The data also supported by ARE, the result obtained were 2.45 and 3.13 for pseudo-second-order and pseudo-first-order, respectively. Therefore, the result approved that adsorption is well described by the pseudosecond-order kinetic model. It means the chemisorption mechanism and 
having strong interaction between the adsorbate and adsorbent. The adsorption mechanism may involve force through electron sharing or exchanged between TCAC and the adsorbate..$^{28}$

Table 5: Pseudo-first-order, pseudo-second-order constants and $\mathrm{R}^{2}$ values for adsorption of acetaminophen on TCAC at $30^{\circ} \mathrm{C}$.

\begin{tabular}{lrrrrrrr}
\hline \multirow{2}{*}{$\begin{array}{l}\text { Initial dye } \\
\text { concentration } \\
\left(\mathrm{mg} \mathrm{L}^{-1}\right)\end{array}$} & $\begin{array}{c}\mathrm{q}_{\mathrm{e} \text { exp }} \\
\left(\mathrm{mg} \mathrm{g}^{-1}\right)\end{array}$ & \multicolumn{2}{c}{ Pseudo-first-order model } & \multicolumn{3}{c}{ Pseudo-second-order model } \\
\cline { 3 - 8 }$\left(\mathrm{qg} \mathrm{gal}^{-1}\right)$ & $\begin{array}{c}\mathrm{K} \\
\left(1 \mathrm{~min}^{-1}\right)\end{array}$ & $\mathrm{R}^{2}$ & $\begin{array}{c}\mathrm{q}_{\mathrm{e} c a l} \\
\left(\mathrm{mg} \mathrm{g}^{-1}\right)\end{array}$ & $\begin{array}{c}\mathrm{K}_{2} \\
\left(1 \mathrm{~min}^{-1}\right)\end{array}$ & $\mathrm{R}^{2}$ \\
\hline 5 & 1.35 & 1.81 & 0.0180 & 0.468 & 3.12 & 0.0079 & 0.961 \\
25 & 8.76 & 1.70 & 0.0196 & 0.947 & 16.31 & 0.0007 & 0.935 \\
50 & 32.43 & 13.30 & 0.0246 & 0.821 & 27.78 & 0.0018 & 0.995 \\
75 & 37.87 & 14.22 & 0.0244 & 0.830 & 33.89 & 0.0023 & 0.998 \\
100 & 40.13 & 9.26 & 0.0290 & 0.671 & 41.15 & 0.0036 & 0.991 \\
\hline
\end{tabular}

\subsection{Thermodynamic Studies}

Through the effect of temperature adsorption thermodynamic can be determined by varies temperature $(303,313$ and $323 \mathrm{~K})$. The Gibb's energy $\left(\Delta \mathrm{G}^{\circ}\right)$, enthalpy $\left(\Delta \mathrm{H}^{\circ}\right)$ and entropy $\left(\Delta \mathrm{S}^{\circ}\right)$ were the parameters for thermodynamic studies and were determined through Equations 12 to 15 . The results were shown as $\Delta \mathrm{S}^{\circ}=-0.95 \mathrm{~kJ}$ mol. $\mathrm{K}^{-1}$ and $\Delta \mathrm{H}^{\circ}=-324.16 \mathrm{~J} \mathrm{~mol}^{-1}$, the negative values obtained implies the adsorption process was exothermic process. This was the process where the energy was released into its surrounding. ${ }^{29}$ The values of $\Delta \mathrm{G}^{\circ}(-34.96$, -25.41 and $-15.87 \mathrm{~kJ} \mathrm{~mol}^{-1}$ ) were more towards negativity as temperature rises which were 303,313 and $323 \mathrm{~K}$ respectively. According to the negative values of $\Delta \mathrm{G}^{\circ}, \Delta \mathrm{S}^{\circ}$ and $\Delta \mathrm{H}^{\circ}$, it is proven that the process is spontaneous and exothermic. The results are comparable with other researcher. ${ }^{30}$

\section{CONCLUSION}

As a conclusion, it was proven that TCAC is adsorbing acetaminophen with $32.43 \mathrm{mg} \mathrm{g}^{-1}$ of adsorption capacity. The equilibrium studies, adsorption kinetic and thermodynamic studies were examined using various initial concentrations and temperatures. As a result, it showed that the Langmuir model is best fitted for this adsorption of acetaminophen onto TCAC through correlation coefficient with supported by smallest error analysis. The Langmuir model indicated monolayer coverage and homogenous site on the adsorbent. Moreover, kinetic studies showed pseudo-second-order is well presented by the adsorption process. Thermodynamic 
studies found that Gibbs energy, $\Delta \mathrm{G}^{\circ}$ is more negativity as all temperature rises from 303 to $323 \mathrm{~K}$, while both $\Delta \mathrm{H}^{\circ}$ and $\Delta \mathrm{S}^{\circ}$ were also negative value. This reflects that the process is spontaneous and exothermic. The innovative approach in this research, by introducing the TCAC as a medium for the adsorption process is relevant for research nowadays. ${ }^{31}$

\section{ACKNOWLEDGEMENTS}

The authors would like to acknowledge the Bridging Grant Universiti Sains Malaysia (304/PJKIMIA/6316498) for financial support for this research work.

\section{REFERENCES}

1. Baalbaki, Z., Sultana, T., Metcalfe, C. \& Yargeau, V. (2017). Chemosphere estimating removals of contaminants of emerging concern from wastewater treatment plants: The critical role of wastewater hydrodynamics. Chemosphere, 178, 439-448, https://doi.org/10.1016/j. chemosphere.2017.03.070.

2. Yacob, H., Yong, E. L., Kim, H. -Y., Oh, J. -E., Noor, Z. Z., Mohd. Din, M. F. et al.. (2017). Identification of pharmaceutical residues in treated sewage effluent in Johor, Malaysia. Malays. J. Civ. Eng., 29(Special Issue 2), 165-173.

3. Barnes, K. K, Kolpin, D. K., Furlong, E. T., Zaugg, S. D., Meyer, M. T. \& Barber, L. B. (2008). A national reconnaissance of pharmaceuticals and other organic wastewater contaminants in the United States I) groundwater. Sci. Total Environ., 402(2-3), 192-200, https://doi. org/10.1016/j.scitotenv.2008.04.028.

4. Price, O. R., Hughes, G. O., Roche, N. L. \& Mason, P. J. (2010). Improving emissions estimates of home and personal care products ingredients for use in EU risk assessments. Integr. Environ. Assess. Manage., 6(4), 677-684, https://doi.org/10.1002/ieam.88.

5. European Medicines Agency. (2016). Guideline on environmental impact assessment for veterinary medicinal products in support of the VICH guidelines GL6 and GL38. London: European Medicines Agency.

6. Boxall, A. B. A., Rudd, M. A., Brooks, B. W., Caldwell, D. J., Choi, K., Hickmann, S. et al. (2012). Pharmaceuticals and personal care products in the environment: What are the big questions? Environ. Health Perspect., 120(9), 1221-1229, https://doi.org/10.1289/ehp.1104477. 
7. Fick, J., Söderström, H., Lindberg, R. H., Phan, C., Tysklind, M. \& Larsson, D. J. (2009). Contamination of surface, ground, and drinking water from pharmaceutical production. Environ. Toxicol. Chem., 28(12), 2522-2527, https://doi.org/10.1897/09-073.1.

8. Advameg, Inc. (2018). How PPCPs enter the environment. Retrieved from http://www.pollutionissues.com/Co-Ea/Consumer-Pollution.html.

9. Environmental Health Division. (2014). Acetaminophen in drinking water. St. Paul, MN: Environmental Health Division. Retrieved from www.health.state.mn.us/eh.

10. Patneedi, C. B. \& Prasadu, K. D. (2015). Impact of pharmaceutical waste on human life and environment. Rasayan J. Chem., 8(1): 67-70.

11. Lishman, L., Smyth, S. A., Sarafin, K., Kleywegt, S., Toito, J., Peart, T. et al. (2006). Occurrence and reductions of pharmaceuticals and personal care products and estrogens by municipal wastewater treatment plants in Ontario, Canada. Sci. Total Environ., 367 (2-3), 544-558, https://doi.org/10.1016/j.scitotenv.2006.03.021.

12. Verlicchi, P., Al Aukidy, M. \& Zambello, E. (2012). Science of the total environment occurrence of pharmaceutical compounds in urban wastewater: Removal, mass load and environmental risk after a secondary treatment; A review. Sci. Total Environ., 429, 123-155, https://doi. org/10.1016/j.scitotenv.2012.04.028.

13. National Center for Biotechnology Information. PubChem database. Acetaminophen, $\quad \mathrm{CID}=1983$, https://pubchem.ncbi.nlm.nih.gov/ compound/acetaminophen.

14. Nawi, M. A. \& Zain, S. M. (2012). Enhancing the surface properties of the immobilized Degussa P-25 Ti-O $\mathrm{O}_{2}$ for the efficient photocatalytic removal of methylene blue from aqueous solution. Appl. Surf. Sci., 258(16), 61486157, https://doi.org/10.1016/j.apsusc.2012.03.024.

15. Bahrudin, N. N. \& Nawi, M. A. (2017). Fabrication of immobilized powdered activated carbon as a sub-layer of $\mathrm{TiO}_{2}$ for the photocatalyticadsorptive removal of phenol. React. Kinet., Mech. Catal., 124(1), 153-169, https://doi.org/10.1007/s11144-017-1319-3.

16. Carabineiro, S. A. C., Thavorn-amornsri, T., Pereira, M. F. R., Serp, P. \& Figueiredo, J. L. (2012). Comparison between activated carbon, carbon xerogel and carbon nanotubes for the adsorption of the antibiotic ciprofloxacin. Catal. Today, 186(1), 29-34, https://doi.org/10.1016/j. cattod.2011.08.020.

17. Langmuir, I. (1917). The constitution and fundamental properties of solids and liquids. J. Franklin Inst., 183(1), 102-105, https://doi.org/10.1016/ S0016-0032(17)90938-X. 
18. Tonucci, M. C., Gurgel, L. V. A. \& de Aquino, S. F. (2015). Activated carbons from agricultural byproducts (pine tree and coconut shell), coal, and carbon nanotubes as adsorbents for removal of sulfamethoxazole from spiked aqueous solutions: Kinetic and thermodynamic studies. Ind. Crops Prod., 74, 111-121, https://doi.org/10.1016/j.indcrop.2015 .05.003.

19. Lompe, K. M., Vo, S., Peldszus, S., Sauvé, S. \& Barbeau, B. (2018). Removal of micropollutants by fresh and colonized magnetic powdered activated carbon. J. Hazard. Mater., 360(March), 349-355, https://doi. org/10.1016/j.jhazmat.2018.07.072.

20. Herbert, F. (1907). Über die adsorption in Lösungen. Z. Phys. Chem., 57U(1), 385-470. https://doi.org/10.1515/zpch-1907-5723.

21. Dada, A. O., Olalekan, A. P., Olatunya, A. M. \& Dada, O. (2012). Langmuir, Freundlich, Temkin and Dubinin: Radushkevich isotherms studies of equilibrium sorption of $\mathrm{Zn}_{2}+$ Unto phosphoric acid modified rice husk. IOSR J. Appl. Chem., 3(1), 38-45, https://doi.org/10.9790/ 5736-0313845.

22. Temkin, M. I. \& Pyzhev, V. (1940). Kinetic of ammonia synthesis on promoted iron catalyst. Acta Physicochim., 12, 327-356.

23. Ho, Y. S. (2004). Citation review of lagergren kinetic rate equation on adsorption reactions. Scientometrics, 59(1), 171-77, https://doi. org/10.1023/B:SCIE.0000013305.99473.cf.

24. Ho, Y. S. \& McKay, G. (1999). Pseudo-second order model for sorption processes. Process Biochem., 34(5), 451-465, https://doi.org/10.1016/ S0032-9592(98)00112-5.

25. Mohd, N., Sudirman, M. F. A. E. \& Draman, S. F. S. (2015). Isotherm and thermodynamic study of paracetamol removal in aqueous solution by activated carbon. J. Eng. Appl. Sci., 10(20), 9516-9520.

26. Çalişkan, E. \& Göktürk, S. (2010). Adsorption characteristics of sulfamethoxazole and metronidazole on activated carbon. Sep. Sci. Technol., 45(2), 244-255, https://doi.org/10.1080/01496390903409419.

27. Balarak, D., Mostafapour, F. K. \& Azarpira, H. (2016). Water remediation using rice shell-based activated carbon for removal of sulfamethoxazole: Error analysis. Pharm. Chem. J., 3(3), 71-77.

28. Ferreira, R. C., De Lima, H. H. C., Cândido, A. A., Junior, O. M. C., Arroyo, P. A. \& De Carvalho, K. Q. (2015). Adsorption of paracetamol using activated carbon of dende and babassu coconut mesocarp. Int. J. Biol. Biomol. Agric. Food. Biotechnol. Eng., 9, 717-722.

29. Dutta, M., Das, U. \& Mondal, S. (2015). Adsorption of acetaminophen by using tea waste derived activated carbon. Int. J. Environ. Sci., 6(2), 270-281, https://doi.org/10.6088/ijes.6031. 
30. Rey-Mafull, C. A., Tacoronte, J. E., Garcia, R., Tobella, J., Llópiz, J. C., Iglesias, A. et al. (2014). Comparative study of the adsorption of acetaminophen on activated carbons in simulated gastric fluid. Springerplus., 3, 1-12, https://doi.org/10.1186/2193-1801-3-48.

31. Saddoud, A., Ellouze, M., Dhouib, A. \& Sayadi, S. (2007). Anaerobic membrane bioreactor treatment of domestic wastewater in Tunisia. Desalination, 207(1-3), 205-215, https://doi.org/10.1016/j.desal.2006 .08 .005 . 